This item was submitted to Loughborough's Research Repository by the author.

Items in Figshare are protected by copyright, with all rights reserved, unless otherwise indicated.

\title{
Employee voice in the Asia Pacific
}

PLEASE CITE THE PUBLISHED VERSION

https://doi.org/10.1111/1744-7941.12274

PUBLISHER

John Wiley \& Sons Ltd @ Australian HR Institute

VERSION

AM (Accepted Manuscript)

\section{PUBLISHER STATEMENT}

This is the peer reviewed version of the following article: WILKINSON, A., MOWBRAY, P. and JIAN-MIN SUN, J., 2018. Employee voice in the Asia Pacific. Asia Pacific Journal of Human Resources, doi:10.1111/1744-7941.12185, which has been published in final form at https://doi.org/10.1111/17447941.12185. This article may be used for non-commercial purposes in accordance with Wiley Terms and Conditions for Use of Self-Archived Versions.

\section{LICENCE}

CC BY-NC-ND 4.0

\section{REPOSITORY RECORD}

Wilkinson, Adrian, James Jian-Min Sun, and Paula Mowbray. 2020. "Employee Voice in the Asia Pacific". Loughborough University. https://hdl.handle.net/2134/35302. 


\title{
Employee Voice in the Asia Pacific
}

\author{
Adrian Wilkinson, Griffith University \\ Paula Mowbray, Griffith University \\ James Jian-Min Sun, University of Auckland
}

Over the past thirty-five years, since Farrell (1983) first applied Hirschman's (1970) concept of voice in relation to employees and Freeman and Medoff (1984) brought in the role of unions, we have accumulated a vast body of literature concerning employee voice. This research has largely spanned across employment relations, human resource management, organisational behaviour and labor economics disciplines.(Wilkinson and Fay 2011) This has provided us with greater insights concerning the institutional and organisational factors that may contribute to the establishment and management of both direct and indirect employee voice mechanisms, along with the delineation of antecedents that may encourage employees to engage in voice behaviour directly to managers. Thus, the notion of employee voice has moved from its traditional roots of indirect, representative union forms of voice, to one that is more inclusive of direct employee-managerial interactions (Mowbray, Wilkinson and Tse, 2015). Employee voice is now seen, therefore, as the opportunity to have a say over employee and employer interests and to participate in organisational decision-making (Barry and Wilkinson 2015), as well as a discretionary behaviour whereby employees may raise ideas, issues, opinions and concerns in order to bring about change (Morrison, 2014).

This Special Issue of the Asia Pacific Journal of Human Resources explores the theme of employee voice in the Asia Pacific. Whilst there is an extensive literature on employee voice in western countries (Freeman, Boxall and Haynes, 2007; Wilkinson et al., 2004, 2014; Morrison, 2011, 2014; Johnstone and Ackers, 2015), we know rather less about the state of employee voice in the Asia Pacific. This gap relates both to institutional factors (regulation, laws) as well as cultural factors, and how these may apply both to the employee voice arrangements and employee voice behaviour. Certainly, governance and representation structures of voice are embedded in particular institutional contexts that have deep historical and cultural roots and therefore we are likely to find significant differences not only between Asia Pacific countries and the rest of the world, but also between and within the Asia Pacific countries themselves.

Although limited in scope and size, if we look to the body of research that has based their voice studies within the Asia Pacific context, these provide a useful starting point to identify our 
current state of knowledge and to suggest where future research should be directed. For example, research on emerging economies has recorded different models of employee voice aimed at promoting employee participation and voice, whereby there are those developed independently, while others are influenced by developed countries. For example, China has adopted a mixed voice model combining the traditional "iron rice bowl" paradigm with Western HR practices (Warner, 2004).

We also see differences in union arrangements across different countries and the extent to which government and employers perceive these favourably. Liu et al.'s (2012) study of a bilateral project on labor between China and US identified significant differences between the Chinese and American contexts, which impacted the implementation of worker-management committees in China. Strong government involvement in these committees contributed to the improved opportunities for voice and workplace democracy within these workplaces. In contrast, a study conducted in Malaysia by Kumar, Lucio and Rose (2013) found that trade unions had issues with visibility and little influence over decision-making due to restrictions from the state and employers. Examining non-union employee representation (NER) in Korea, Kim and Kim (2004) found that there were structural weaknesses to NERs and that union members were more satisfied with their union arrangements than their non-union counterparts were with the non-union works councils. A later study conducted in Korea by Shin (2014) examined the influence of unions in relation to the adoption of high performance work systems (HPWSs), and in this instance found that there were tensions involved with the employers when more comprehensive HPWSs were used.

A number of studies have also been conducted in the region concerning voice that is targeted directly to managers, and these have focused on behaviours associated with voice. Scholars using Chinese samples identified the antecedents to two different types of voice, promotive and prohibitive voice (Liang, Farh and Farh, 2012), finding that felt obligation was most strongly related to promotive voice, psychological safety was most strongly related to prohibitive voice and organization-based self-esteem was reciprocally related to promotive voice. Applying the promotive and prohibitive voice types to power distance (Hofstede, 1984), Hsiung and Tsai's (2017) study in Taiwan determined that power distance orientation had a negative relationship with promotive voice but did not have a significant relationship with prohibitive voice. Although, in a situation where both activated negative mood and group voice climate were high, power distance orientation no longer had a negative relationship with promotive voice and even had a positive relationship with prohibitive voice. Matsunaga (2015) found that in Japan, employees may take different voice strategies in different situations. 
Proactive personality was positively associated with assertive strategies, while relationship maintenance goal orientation was linked to conciliatory, non-confrontational strategies.

Studies on leadership behaviours have shown that paternalistic leadership, one of the traditional Asian constructs, can both facilitate or hinder employee voice (Zhang, Huai and Xie, 2015). Authoritarian paternalistic leaders reduce employee voice by reducing their status judgment. Benevolent paternalistic leaders encourage employee voice by enhancing both leader member exchange (LMX) and status judgment. Moral paternalistic leaders positively influence employee voice mainly through LMX processes. Humble leadership, also considered to be more likely to occur within the Asian context, has been linked to greater motivation to voice under conditions of high personal sense of power and low power distance (Lin et al., 2017). Asia Pacific Journal of Human Resources is an applied, peer-reviewed journal which aims to communicate the development and practice of the field of human resources within the Asia Pacific region. The journal publishes the results of research, theoretical and conceptual developments, and examples of current practice. The overall aim is to increase the understanding of the management of human resources in an organisational setting. Both macro and micro level studies, conceptual and empirical papers are encouraged. In terms of geographic coverage of the region, we are happy to consider any Asian countries, including the Middle East, as we explore the concept and practice of employee voice mechanisms in the Asia Pacific.

Some of the areas that could be addressed include:

- empirical papers on country-specific voice practices, and papers that extend employee voice theory;

- relationship between HRM and trade unions, and other stakeholders/institutional actors;

- literature reviews on employee voice in the region;

- cross-country comparative studies in the region;

- employee voice in national contexts where silence might be the norm;

- how the institutional and cultural factors within non-western countries may contribute to silence

- whether voice in these contexts can be activated by workers or whether it is provided by management;

- challenging predominant assumptions about voice effectiveness drawn out of Western economies;

- novel voice mechanisms that may exist in the Asia Pacific; and

- voice and participation paradigms in the Asia Pacific. 
This list is indicative only. The call is not prescriptive other than the theme of employee voice in the Asia Pacific. The editors of the Special Issue are happy to discuss initial ideas for articles via email.

Manuscripts should be prepared according to APHR guidelines. These are available athttp://onlinelibrary.wiley.com/journal/10.1111/(ISSN)1744-

\section{1/homepage/ForAuthors.html}

Manuscripts should be a maximum of 8,500 words (1.5 spacing). Each submission should have a separate title page with author details.

Submitted papers must be based on original material and not under consideration by any other journal or outlet.

Manuscripts should be submitted online using the journal's submission page.

All submitted papers will undergo a full double-blind review process, and will be evaluated by an Editor of the Special Issue and at least two independent reviewers, including members of the journal's Editorial Board.

Publication Schedule:

Full paper submission 31st October 2018

Review reports $\quad 1^{\text {st }}$ December 2018

Revised paper submission 15th January 2019

Final manuscript submission to publisher 15th July 2019

Please feel free to contact one of the guest editors via email:

Adrian Wilkinson: Adrian.Wilkinson@griffith.edu.au

Paula Mowbray: P.Mowbray@griffith.edu.au

James Jian-Min Sun: chinajms@126.com

\section{References}

Barry, M and A Wilkinson (2016) Pro-social or pro management: a critique of the conception of employee voice as a pro-social behaviour within Organisational Behaviour, British Journal of Industrial Relations, doi: 10.1111/bjir.12114.

Farrell, D. (1983) Exit, voice, loyalty, and neglect as responses to job dissatisfaction: A multidimensional scaling study. Academy of Management Journal, 26(4), 596-607. 
Freeman, R., P Boxall and P Haynes (2007) What Workers Say: Employee Voice in the AngloAmerican Workplace,Cornell University Press, New York.

Freeman, RB and JL Medoff (1984). What do unions do?, Basic Books, New York.

Hirschman, AO (1970) Exit, voice, and loyalty: Responses to decline in firms, organizations, and states, Harvard University Press, Cambridge, MA.

Hofstede, G (1984) Culture's consequences: International differences in work-related values (Vol. 5), Sage Publications, California.

Hsiung HH and WC Tsai (2017) The Joint Moderating Effects of Activated Negative Moods and Group Voice Climate on the Relationship between Power Distance Orientation and Employee Voice Behavior. Applied Psychology: An International Review, 66(3), 487514.

Johnstone S and P Ackers (eds.) (2015) Finding a voice at work?: new perspectives on employment relations, Oxford University Press, Oxford.

Kim DO and HK Kim (2004) A comparison of the effectiveness of unions and non-union works councils in Korea: can non-union employee representation substitute for trade unionism? The International Journal of Human Resource Management, 15(6), 10691093.

Kumar N, MM Lucio and RC Rose (2013) Workplace industrial relations in a developing environment: barriers to renewal within unions in Malaysia. Asia Pacific Journal of Human Resources, 51, 22-44.

Liang, J, C Farh and JL Farh (2012). Psychological antecedents of promotive and prohibitive voice: A two-wave examination. Academy of Management Journal, 55(1), 71-92.

Lin X, ZX Chen, HHM Tse, W Wei, and C Ma (2017) Why and When Employees Like to Speak up More Under Humble Leaders? The Roles of Personal Sense of Power and Power Distance. Journal of Business Ethics, 1-14.

Liu J, LS Root, JP Beck and RW Zullo (2012) Creating worker-management committees to promote worker' voice in China. Journal of Workplace Rights, 17(1), 3-22.

Matsunaga, M (2015) Development and validation of an employee voice strategy scale through four studies in Japan. Human Resource Management, 54(4), 653-671.

Morrison, EW (2011) Employee voice behavior: Integration and directions for future research. The Academy of Management Annals, 5(1), 373-412. 
Morrison, EW (2014) Employee voice and silence. The Annual Review of Organizational Psychology and Organizational Behavior, 1(1), 173-197.

Mowbray PK, A Wilkinson and HHM Tse (2015) An integrative review of employee voice: Identifying a common conceptualization and research agenda. International Journal of Management Reviews, 17(3), 382-400.

Shin E (2014) Unions and the adoption of high-performance work systems in Korea: moderating roles of firms' competitive strategies. International Journal Of Human Resource Management, 25(13), 1858-1880.

Warner M (2004) 'Human Resource Management in China revisited: introduction', International Journal of Human Resource Management, 15(4-5), 617-634.

Wilkinson, A. and C Fay (2011) 'New times for employee voice?', Human Resource Management, 50(1): 65-74.

Wilkinson, A., T Dundon, M Marchington, and P Ackers (2004) 'Changing patterns of employee voice', Journal of Industrial Relations, 46(3): 298-322.

Wilkinson A, J. Donaghey, T Dundon and R Freeman (eds) (2014) The Handbook of Research on Employee Voice, Edward Elgar Press, Cheltenham.

Zhang Y, MY Huai and YH Xie (2015) Paternalistic leadership and employee voice in China: A dual process model. The Leadership Quarterly, 26(1):25-36 